\title{
Linfoma cutâneo primário de pequena e média célula T CD4+ pleomórfico
}

\section{Primary cutaneous CD4 + small/ médium- sized pleomorphic T-cell lymphoma}

0 Linfoma cutâneo primário de pequena e média célula T CD4+ pleomórfico representa 2 a 3\% de todos os linfomas cutâneos T e caracteriza-se pelo infiltrado na derme com extensão ao tecido celular subcutâneo de linfócitos T pleomórficos de pequeno a médio tamanho $0^{1,2}$. Esta patologia afeta sobretudo adultos entre a $5^{\mathrm{a}}$ e $6^{\mathrm{a}}$ décadas de vida, apresentando-se geralmente sob a forma de lesões únicas, ou mais raramente, múltiplas, na face, pescoço, tronco ou membros superiores ${ }^{1-3}$. As lesões variam desde pápulas, placas, lesões nodulares ou tumores de coloração violácea, que podem ulcerar ${ }^{1-3} \cdot 0$ diagnóstico é realizado através do exame histológico e imunohistoquímico das lesões e o prognóstico é geralmente benigno ${ }^{1-3}$.

Os autores apresentam 0 caso de uma mulher de 72 anos de idade, leucodérmica, hipertensa, com surgimento há 3 meses de pápulas de coloração violácea no antebraço esquerdo, que coalesceram

e evoluíram para a forma de tumor ulcerado com

sinais inflamatórios (Figura 1). No último mês surgimento de outras lesões pápulo-nodulares na coxa direita (Figura 2) e mama esquerda, não dolorosas ou pruriginosas. A doente negava perda ponderal, febre, anorexia ou outra sintomatologia. Analiticamente não apresentava alterações relevantes e a biópsia das lesões do antebraço esquerdo revelou infiltração massiva da derme por histiócitos e linfócitos pleomórficos compatíveis com Linfoma primário de pequena e média célula T CD4+ pleomórfico. Realizou Tomografia computorizada bem como mielograma e biopsia óssea que excluíram atingimento extra cutâneo. A doente realizou radioterapia sob as lesões do antebraço e quimioterapia com ciclofosfamida, vincristina, mitoxantrona e prednisona com melhoria das lesões cutâneas mas faleceu 5 meses mais tardes no contexto de Síndrome de Guillain-Barré.

\section{Bibliografia}

1. Willemze R, Jaffe ES, Burg G, et al. WHO-EORTC classification for cutaneous lymphomas. Blood. 2005; 105(10): 3768-3785

2. Lan TT1, Brown NA, Hristov AC. Controversies and considerations in the diagnosis of primary cutaneous CD4+ small/medium T-cell lymphoma. Arch Pathol Lab Med. 2014 0ct; 138(10):1307-18.

3. Williams VL1, Torres-Cabala CA, Duvic M. Primary cutaneous small- to medium-sized CD4+ pleomorphic T-cell lymphoma: a retrospective case series and review of the provisional cutaneous lymphoma category. Am J Clin Dermatol. 2011 Dec 1; 12(6):389-401.

\section{Diagnóstico}

\section{Linfoma primário de pequena} e média célula T $\mathrm{CD} 4^{+}$pleomórfico

\section{Eunice Oliveira, Maria Manuela Soares.}

Hospital de Egas Moniz. Serviço de Medicina 2. Centro Hospitalar de Lisboa Ocidental

Correspondencia: oliveiraeunice@yahoo.com

Cómo citar este artículo: Oliveira E, Soares MM.

Linfoma primário de pequena e média célula T CD4+ pleomórfico. Galicia Clin 2016; 77 (2): 83

Recibido: 27/11/2015; Aceptado: 17/01/2016

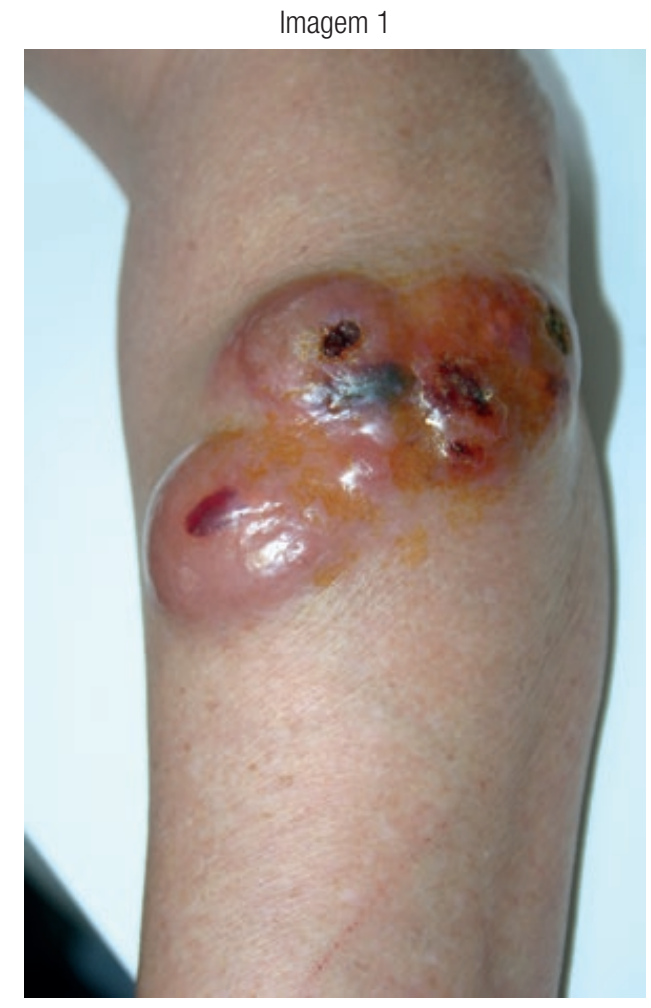

Imagem 2

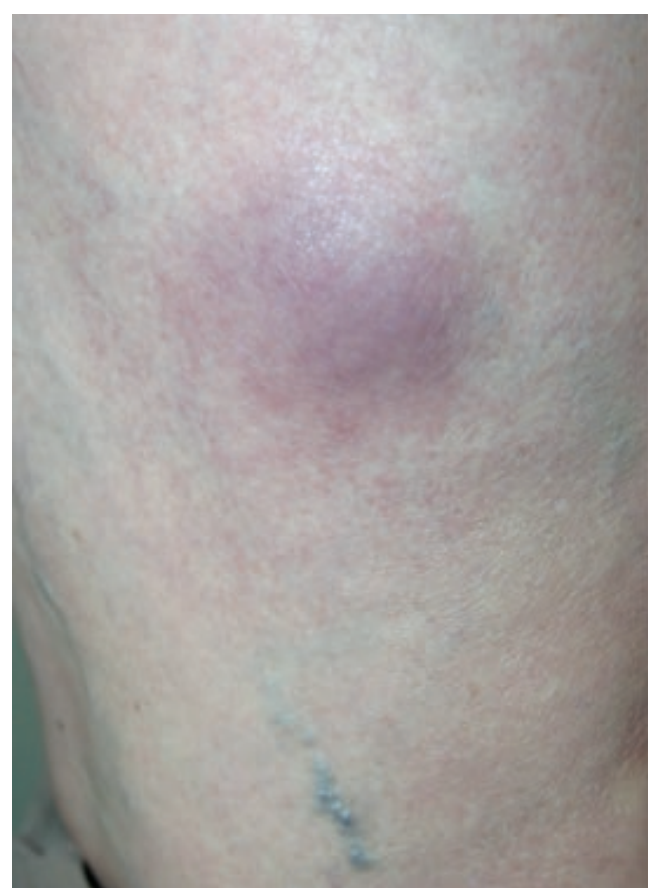

